\title{
PEMBERANTASAN PERDAGANGAN ORANG MELALUI INSTRUMEN HUKUM NASIONAL DAN HUKUM INTERNASIONAL DI INDONESIA*
}

\author{
Deypend Tommy Sibuea \\ Magister Ilmu Hukum Universitas Diponegoro \\ Tembalang, Kecamatan Tembalang, Kota Semarang, Jawa Tengah \\ Email: deypendsibuea@gmail.com
}

\begin{abstract}
Human trafficking is a modern form of slavery, occurring both nationally and internationally. With the development of information technology, communication and transformation then the mode of human trade increasingly sophisticated. Human trafficking becomes one of the five greatest crimes in the world to be overcome because of the effects not only on the economic, but also on the political, cultural and humanitarian aspects. It is therefore necessary to review the forms of human trafficking, its causal factors and legal instruments that can be used to combat trafficking. Answering these problems then this research is done by normative legal research methods. The results of research show that the forms of people's engagement include sexual exploitation, force labor, domestic slavery, illegal adoption of illegitimate children, debt bondage, mail order brides, and human organs trade. The results also show that poverty, population movement, discrimination and patriarchal culture are the factors causing human trafficking. Give the dangerous nature of trafficking in persons, the state or government of Indonesia should be responsible for preventing and overcoming human trafficking with existing legal instruments.
\end{abstract}

Keywords: Eradication, Human Trafficking, in Indonesia

\begin{abstract}
Abstrak
Perdagangan orang menjadi satu dari lima kejahatan terbesar di dunia yang harus diatasi karena dampaknya tidak hanya pada aspek ekonomi, tapi juga pada aspek politik, budaya dan kemanusiaan. Oleh karena itu perlu dikaji kembali bentuk-bentuk perdagangan manusia, faktorfaktor penyebabnya serta instrumen hukum yang dapat digunakan untuk memberantas perdagangan manusia. Menjawab permasalahan tersebut maka penelitian ini dilakukan dengan metode penelitian hukum normatif. Hasil penelitian menunjukkan bentuk-bentuk perdangangan orang meliputi eksploitasi seksual, kerja paksa, perbudakan dalam rumah tangga, adopsi anak antarnegara secara ilegal, penjeratan utang, pengantin pesanan melalui e-mail, dan perdagangan organ tubuh manusia. Hasil penelitian juga menunjukkan bahwa kemiskinan, perpindahan penduduk, diskriminasi dan juga budaya patriarki menjadi faktor-faktor penyebab terjadinya perdagangan manusia. Mengingat betapa berbahayanya kejahatan perdagangan orang, maka sudah seharusnya negara atau pemerintah Indonesia bertanggung jawab untuk mencegah dan menanggulangi perdagangan manusia dengan perangkat hukum yang telah tersedia.
\end{abstract}

Kata Kunci: Pemberantasan, Perdagangan Orang, di Indonesia

\footnotetext{
*Naskah diterima: 02 Maret 2018, direvisi: 08 Maret 2018, disetujui untuk terbit: 27 Maret 2018
} 
Deypend Tommy Sibuea: Pemberantasan Perdagangan Orang Melalui Instrumen Hukum..

\section{PENDAHULUAN}

Perdagangan orang (human traficking) merupakan masalah klasik yang selalu terjadi sepanjang masa. Masalah perdagangan manusia merupakan sejarah kelam umat manusia, yang bahkan juga telah direkam dalam kitab-kitab suci. ${ }^{1}$

Dewasa ini perdagangan orang juga menjadi salah satu dari lima kejahatan terbesar di dunia yang harus ditanggulangi karena akibat yang ditimbulkan tidak saja pada aspek ekonomi, tetapi juga aspek politik, budaya dan kemanusiaan. ${ }^{2}$ Kelima kejahatan itu adalah perdagangan obat-obatan terlarang, perdagangan senjata illegal, perdagangan orang, kejahatan di bidang hak kekayaan intelektual, dan pencucian uang. ${ }^{3}$

Perdagangan orang merupakan kejahatan yang sangat jahat dan merupakan salah satu kejahatan yang mengalami pertumbuhan paling cepat di dunia. $^{4}$ Menurut informasi yang diterbitkan oleh US Department of Justice dan publikasi yang diterbitkan oleh PBB, ditemukan data bahwa 700 ribu sampai

\footnotetext{
Hakristuti Hakrisnowo, Laporan Perdagangan Manusia di Indonesia, Sentra HAM UI, Hlm. 4

2 Ririen Ambarsari, Faniko Andiyansyah, Anugrah Adiputro Soewandi, Kajian Yuridis Tentang Perlindungan Hukum Terhadap Perempuan dan Anak Korban Human Trafficking, Jurnal Panorama Hukum Vol. 1 No. 1 Juni 2016, Hlm. 15

${ }^{3}$ Moises Na'im, The Fourth Annual Grotius Lecture: Five Wars of Globalization, American University of International Law Review, Vol. 18, 2002, Hlm. 3-12

${ }^{4}$ Sasha L. Nel, Victim of Human Trafficking: Are They Adequately Protected in the United States?, Chicago-Kent Jurnal of International and Comparative Law, 2005, Hlm. 3
}

dengan empat juta orang setiap tahun diperjualbelikan (dijual, dibeli, dikirim, dan di paksa bekerja diluar kemauannya) di seluruh dunia yang sebagian besar berasal dari negara-negara berkembang yang rendah tingkat ekonominya, untuk dibawa ke negara-negara maju. ${ }^{5}$ Sebagai bagian dari negara berkembang, sulit bagi Indonesia untuk dikecualikan dari fenomenon ini, yakni sebagai "negara pengirim" atau "negara sumber". 6

US Departement of Justice dalam laporannya juga melampirkan kondisi terkini terkait dengan perdagangan orang yang terjadi di Indonesia sebagai berikut:

a. Indonesia merupakan source country bagi orang yang diperdagangkan, terutama perempuan dan anak-anak;
b. Para korban umumnya diperdagangkan untuk tujuan eksploitasi seksual dan pekerja;

c. Negara tujuan termasuk Hongkong, Singapura, Taiwan, Malaysia, Brunei, Negara-negara Teluk Persia, Australia, Korea Selatan dan Jepang;

d. Pemerintah belum sepenuhnya melakukan upaya yang sungguhsungguh untuk mencegah terjadinya perdagangan manusia, walau masalah ini sudah lebih diperhatikan dibandingkan dengan masa sebelumnya. $^{7}$

Perdagangan orang (human trafficking) merupakan bentuk perbudakan modern, terjadi baik dalam

\footnotetext{
${ }^{5}$ Hakristuti Hakrisnowo, Op.Cit. Hlm. 7

${ }^{6}$ Ibid, Hlm. 7

${ }^{7}$ US Departement of Justice dalam Hakristuti Hakrisnowo, Ibid, Hlm. 8
} 
tingkat nasional maupun internasional. Dengan perkembangan teknologi informasi, komunikasi dan tranformasi maka modus perdangan manusia semakin canggih. ${ }^{8}$ Pelaku Trafficking dilakukan oleh: Ayah kandung, Ibu angkat, Suami, Pacar, Tetangga, Teman, Pengepul PRT, Calo (orang tak dikenal), mucikari/germo dan jaringan prostitusi. Dari siapa yang menjadi Traffickers-nya dapat dikatakan bahwa, kecuali calo dan jaringan prostitusi, semuanya adalah orang-orang yang mempunyai relasi atau hubungan dengan korban, baik dalam relasi sekedar teman, maupun tetangga dan pacar, ternyata juga termasuk orang-orang yang sudah dipercaya oleh korban, termasuk orang yang dicintai korban.

Tidak bisa di pungkiri bahwa masalah perdagangan orang menimbulkan keprihatinan di berbagai kalangan. Masalah yang berskala nasional bahkan telah masuk lingkup internasional ini membuat berbagai pihak memberikan perhatian khusus, apalagi korbannya tidak sedikit jumlahnya. Pemerintah Indonesia yang berkewajiban memberikan perlindungan pada warga negaranya dinilai kurang serius menangani masalah ini.

Oleh sebab itu, perlu kiranya dilakukan penelitian yang bertujuan untuk mengetahui bentuk-bentuk dan faktorfaktor penyebab terjadinya kejahatan perdagangan orang serta kebijakan dalam pemberantasan kejahatan perdagangan

\footnotetext{
B. Rahmanto, 2005, Perdagangan Perempuan Dalam Jaringan Pengedaran Narkotika, Yayasan Obor Indonesia, Jakarta, Hlm. 12.
}

orang di Indonesia baik menurut instrumen hukum nasional dan hukum internasional.

\section{METODE PENELITIAN}

Pada penulisan ini peneliti menggunakan jenis penelitian hukum normatif yaitu penelitian dilakukan dengan cara meneliti bahan pustaka (data sekunder) yang datanya diperoleh dari penelitian, jurnal, buku, maupun berita media massa baik cetak maupun elektronik berkaitan dengan praktikpraktik perdagangan manusia. Sehubungan dengan penulisan ini penulis menggunakan metode penelitian normatif maka dari itu dilakukan pendekatan dengan jalan menelaah norma-norma hukum dan peraturan perundangundangan terkait dengan kejahatan perdagangan orang.

\section{HASIL DAN PEMBAHASAN}

\section{Bentuk-Bentuk Perdagangan Orang \\ Kejahatan}

Perdagangan orang merupakan salah satu bentuk perlakuan terburuk dan pelanggaran harkat dan martabat manusia, dengan sendirinya merupakan pelanggaran hak asasi manusia. ${ }^{9}$ Protokol Palermo $2000 \quad$ mendefinisikan perdagangan orang sebagai Perekrutan, pengiriman, pemindahan, penampungan, atau penerimaan seseorang, dengan ancaman atau penggunaan kekerasan, atau bentuk-bentuk pemaksaan lain, penculikan, penipuan, kecurangan,

9 Nurhenny, H, 2010, Tindak Pidana Perdagangan Orang Kebijakan Hukum Pidana dan Pencegahannya, Sinar Grafika, Jakarta, Hlm. 307 
Deypend Tommy Sibuea: Pemberantasan Perdagangan Orang Melalui Instrumen Hukum..

penyalahgunaan kekuasaan atau posisi rentan, atau memberi atau menerima bayaran atau menfaat atau memperoleh ijin dari orang yang mempunyai wewenang atas orang lain untuk tujuan eksploitasi.

Bentuk-bentuk perdagangan orang yang terjadi di suatu negara dengan negara lain memiliki karakteristik yang berbeda, tetapi secara umum bentukbentuknya meliputi eksploitasi seksual, kerja paksa, perbudakan dalam rumah tangga, adopsi anak antarnegara secara illegal, penjeratan utang, pengantin pesanan melalui $e$-mail, dan perdagangan organ tubuh manusia.

\section{a. Eksploitasi Seksual}

Eksploitasi seksual merupakan salah satu bentuk perdagangan orang yang banyak terjadi di berbagai negara. Eksploitasi seksual banyak digunakan oleh pelaku trafficking untuk mendapatkan perempuan dan anak-anak setelah penjeratan uang. Eksploitasi seksual ini merupakan bisnis haram yang paling banyak mendatangkan keuntungan materi dibandingkan dengan bentukbentuk perdagangan orang yang lain. Diperkirakan lebih dari 1.000 .000 anakanak yang menjadi korban eksploitasi seksual. ${ }^{10}$ Secara umum modus operandi pelaku di berbagai negara antara lain, menawarkan pekerjaan dengan gaji yang menggiurkan dan "memesan” langsung ke

10 Meril Enugene Anthes, Chester James Taylor 2005 Grand Prize Winner: Regarding Women and Children: Using International Trade Relations to Stem the Growing Tide of the Sexula Exploitation of Women and Children, International Trade Law Journal, Vol. 14, 2005, Hlm. 69 orang tua atau keluarga terdekat bahkan dengan paksaan. ${ }^{11}$

Di Indonesia perdagangan seks ini juga sering kali terjadi. Biasanya korban adalah perempuan dan anak-anak melalui berbagai macam cara, salah satunya adalah ajakan untuk bekerja di luar negeri dengan gaji yang tinggi. Persoalan utama perdagangan orang di Indonesia adalah lemahnya penegakan hukum dan tindakan-tindakan yang diambil pemerintah terutama dalam kaitannya dengan penyelundupan orang ke luar negeri, seperti ke Australia. ${ }^{12}$

\section{b. Kerja Paksa}

Dikatakan kerja paksa jika pekerjan atau pelayanan itu dilakukan dengan ancaman hukuman dan dilakukan tidak dengan sukarela.

Kerja paksa memiliki bentuk, yakni: ${ }^{13}$

\section{1) Bonded Labor}

Bonded labor adalah pekerjaan yang dilakukan dengan cara penjeratan utang, yang di dalamnya tidak ditentukan syarat dan ketentuan pelayanan yang harus dilakukan untuk melunasi utang korban dan pelaku sendiri secara tidak layak menilai bentuk pelayanan korban. Dengan kata lain, yang menentukan semua itu bukan korban, melainkan pelaku sendiri.

\section{2) Child Labor}

11 Mahrus Ali, Bayu Aji Pramono, 2011, Perdagangan Orang: Dimensi, Instrumen Internasional dan Pengaturannya di Indonesia, Citra Aditya Bakti, Yogyakarta, Hlm. 27

12 Mahrus Ali dan Bayu Pramono Aji, Log. Cit. Hlm. 27

${ }^{13}$ Ibid, Hlm. 34-36 
Child Labor diartikan sebagai pekerjaan yang besar kemungkinannya membahayakan kondisi anak dan sering berpengaruh pada pendidikan mereka.

\section{3) Forced Labor}

Forced labor diartikan sebagai pekerjaan di mana korban dipaksa bekerja di bawah ancaman kekerasan atau hukuman. Kerja paksa ini umumnya dilakukan secara tersembunyi, tidak di tempat-tempat umum, tidak berperikemanusiaan, dan menyebar luas. Pelaku sering melarang korban untuk berada di tempat-tempat umum dan menyiksa mereka supaya tetap berada di tempat penyekapan.

Beberapa penyebabnya adalah rendahnya upah/gaji, minimnya aturan atau control terhadap kondisi kenyamanan kerja dan tingginya permintaan terhadap pekerja dengan upah yang murah.

\section{c. Perbudakan dalam Rumah Tangga}

Perbudakan dalam rumah tangga pada dasarnya merupakan imbas lanjutan dari kerja paksa dan korbannya pun tidak hanya perempuan dan anak-anak, tetapi juga laki-laki. Umumnya mereka berasal dari negara-negara berkembang (developing countries), seperti negaranegara di Afrika, Thailand, Kamboja, dan Indonesia. Dengan keterbatasan pengetahuan yang dimiliki, mereka dengan mudah terpengaruh oleh bujuk rayu pelaku dan dijadikan objek perbudakan dalam rumah tangga. Seperti yang terjadi pada kerja paksa, modus operandi pelaku membuat untuk membuat korban tidak memiliki kekuatan untuk melawan adalah dengan mengirim mereka ke negara di mana Bahasa yang digunakan tidak sama dengan Bahasa ibu korban.

\section{d. Adopsi Anak Antarnegara Secara Ilegal}

Bentuk ini lazim terjadi di Asia Tengah seperti Kazakstan dan menempati urutan kedelapan dunia dalam konteks penjualan anak-anak. Tujuan adopsi anak ini sebenarnya untuk kepentingan perdagangan orang yaitu penjualan anak. Anak-anak didatangkan dari negaranegara di Asia Tengah biasanya anakanak yang lahir dari rumah sakit yang keberadaannya tidak terdaftar sehingga dengan mudah diadopsi untuk kepentingan yang bersifat ekonomis. ${ }^{14}$

Dalam melakukan kejahatan ini sering kali pelaku "menyuap" aparat penegak hukum dan pejabat pemerintah setempat agar mereka mendapatkan bantuan dalam bentuk pelolosan terhadap dokumen-dokumen palsu yang merupakan salah satu syarat yang harus dipenuhi untuk diperbolehkannya adopsi anak.

\section{e. Penjeratan Utang}

Penjeratan utang merupakan salah satu bentuk modus operandi dari perdagangan orang. Utang ini terdiri atas sejumlah uang yang harus dibayar kepada keluarga korban dan pelaku, ongkos transport, uang "tutup mulut" yang diberikan kepada pejabat atau aparat penegak hukum, dan biaya hidup korban

\footnotetext{
${ }^{14}$ Ibid, Hlm. 38
} 
Deypend Tommy Sibuea: Pemberantasan Perdagangan Orang Melalui Instrumen Hukum..

yang ditanggung pelaku. Parahnya lagi adalah jumlah uang yang harus dibayar kepada keluarga dan pelaku itu ternyata diduakalipatkan dan disertai dengan bunga untuk masing-masingnya. ${ }^{15}$

Untuk mencegah korban melarikan diri sebelum mereka melunasi utangnya, pelaku biasanya menempatkan mereka di apartemen yang dijaga oleh satu orang penjaga atau lebih, pabrik, rumah pelaku, atau rumah pelacuran. Apabila korban mencoba melarikan diri, cara yang dilakukan oleh pelaku adalah dengan mendeportasi mereka ke suatu negara yang tidak dikenal oleh korban. Negara yang dituju adalah negara yang jauh dari negara asal korban dan menggunakan bahasa yang berbeda dengan Bahasa ibu korban. Kesulitan Bahasa inilah yang menyebabkan korban tidak memiliki kemampuan untuk melarikan diri. Pelaku juga tidak jarang menyekap atau menahan korban di suatu tempat yang tida diketahui oleh mereka.

\section{f. Pengantin Pesanan}

Pengantin pesanan (mail-order brides) juga merupakan salah satu bentuk perdagangan orang. Mail-order brides merupakan suatu terminologi yang merujuk pada pembelian barang atau pelayanan melalui fasilitas e-mail. Pembeli memesan produk (perempuan) yang diinginkan melalui beberapa

15 Shelly Case Inglis, Expanding International and National Protections Againts Trafficking for Forced Labor Using a Human Rights Framework, Buffalo Human Right Law Review, Vol. 7, 2001, Hlm. 70 metode, seperti melalui telepon atau website. $^{16}$

Di Indonesia, praktik perbudakan berkedok pernikahan dan pengantin pesanan dilakukan oleh pria warga negara asing dengan wanita warga negara Indonesia. Salah satu modus operandi perdagangan orang yang lain adalah pengantin pesanan (mail border bride) yang merupakan pernikahan paksa dimana pernikahannya diatur orang tua. Perkawinan pesanan ini menjadi perdagangan orang apabila terjadi eksploitasi baik secara seksual maupun ekonomi melalui penipuan, penyesengsaraan, penahanan dokumen, sehingga tidak dapat melepaskan diri dari eksploitasi, serta ditutupnya akses informasi dan komunikasi dengan keluarga. ${ }^{17}$

Ada dua bentuk perdagangan melalui perkawinan, yaitu pertama, perkawinan digunakan sebagai jalan penipuan untuk mengambil perempuan tersebut dan membawa ke wilayah lain yang sangat asing, namun sesampai di wilayah tujuan perempuan tersebut dimasukkan dalam prostitusi. Kedua, adalah perkawinan untuk memasukkan perempuan kedalam rumah tangga untuk mengerjakan pekerjaan-pekerjaan domestik yang sangat eksploitatif bentuknya. Fenomena pengantin pesanan ini banyak terjadi di masyarakat keturunan Cina di Kalimantan Barat dengan para suami berasal dari Taiwan walaupun dari Jawa Timur

\footnotetext{
${ }^{16}$ Mail Order Bride, wikipedia.com

${ }^{17}$ Mahrus Ali dan Bayu Aji Pramono, Op. Cit, Hlm. 39
} 
diberitakan telah terjadi beberapa kasus serupa. $^{18}$

\section{Faktor-Faktor \\ Penyebab \\ Kejahatan Perdagangan Manusia}

\section{a. Kemiskinan, Perpindahan Penduduk, dan Diskriminasi}

Kemiskinan sesungguhnya tidak hanya terkait dengan perdagangan orang, tetapi juga terkait dengan berbagai macam persoalan yang lain. Kejahatan terjadi salah satunya disebabkan oleh alasan kemiskinan. Seseorang melakukan kejahatan salah satu tujuannya karena ingin mempertahankan hidup di tengah kondisi ekonomi yang serba sulit. Kemiskinan juga menyebabkan terjadinya perdagangan orang. Tidak sedikit yang "rela" menjadi korban perdagangan orang karena alasan kemiskinan. Banyak pula orang tua yang menjual anaknya kepada orang lain untuk dijadikan objek perdagangan orang karena berharap hal itu akan mengurangi beban ekonomi mereka. ${ }^{19}$

Kemiskinan ternyata dapat memunculkan penyebab lain terjadinya perdagangan orang, yakni adanya perpindahan penduduk dari suatu negara ke negara lain. Perpindahan penduduk merupakan salah satu faktor penyebab terjadinya peningkatan angka perdagangan orang dari tahun ke tahun. Orang-orang yang melakukan perpindahan penduduk itu umumnya berasal dari negara-negara berkembang.

\footnotetext{
${ }^{18}$ Mahrus Ali dan Bayu Aji Pramono, Log. Cit. Hlm. 39

${ }^{19}$ Ibid, Hlm. 50
}

Eropa Timur dan bekas Uni Soviet merupakan tempat relatif aman terjadinya perpindahan penduduk. Tujuan utama mereka adalah Uni Emirat Arab, Albania, Siprus, Jerman, Italia, Kosovo, Malaysia, Korea Selatan. Di Eropa diperkirakan tak kurang dari 500.000 orang memasuki negara itu melalui proses perpindahan penduduk dan setengahnya dilakukan oleh pelaku. $^{20}$

Kebanyakan dari mereka adalah perempuan dan anak-anak. Banyaknya perempuan dan anak-anak yang menjadi korban perdagangan orang disebabkan oleh adanya diskriminasi terutama dalam kaitannya dengan akses terhadap harta keluarga dan pendidikan. Di negaranegara berkembang perempuan biasanya, tetapi tidak selalu, memiliki keterbatasan akses terhadap harta keluarga sehingga hal itu menyebabkan mereka mencari alternatif lain untuk bisa bertahan hidup. Mereka secara "rela" menjadi korban perdagangan orang karena hal itu merupakan alternatif terakhir yang dapat dilakukan.

\section{b. Budaya Patriarki}

Budaya patriarki merupakan faktor berikutnya yang menyebabkan terjadinya perdagangan orang. Budaya Patriarki adalah budaya yang menganggap bahwa anak laki-laki memiliki kelebihan dan keutamaan dibandingkan dengan anakanak perempuan terutama dalam hubungannya dengan akses pada harta

\footnotetext{
${ }^{20}$ Tom Abokata, Human Trafficking, Human Rights and the Nationality, Immigration and Asylum Act, Europion Human Rights Law Review, 2003, Hlm. 410
} 
Deypend Tommy Sibuea: Pemberantasan Perdagangan Orang Melalui Instrumen Hukum..

keluarga dan pendidikan. Budaya ini merupakan cara pandang yang meminggirkan kaum perempuan dan the voiceless lainnya. Cara pandang ini menganggap perempuan sebagai kaum atau warga nomor dua atau nomor kesekian. Ideologi ini memandang anakanak, minoritas, penyandang cacat dan yang lainnya sebagai obyek, dan bukan subyek. Ideologi ini jelas merugikan kaum perempuan dan anak-anak serta kelompok tersisih lainnya. ${ }^{21}$

Di Indonesia budaya patriarki ini menjadi salah satu faktor terjadinya perdagangan orang. Kuatnya ideologi patriarki di masyarakat dan negara menjadi salah satu penyebab terjadinya perdagangan orang. ${ }^{22}$

\section{Instrumen Nasional dan Instrumen Internasional Dalam Rangka Pemberantasan Perdagangan Orang Di Indonesia}

\section{a. Instrumen Internasional}

Terdapat berbagai instrumen internasional yang berkaitan dengan masalah perdagangan orang atau human trafficking. Instrumen-instrumen tersebut adalah:

1) Universal Declaration of Human Rights;

2) International Covenant on Civil and Political Rights;

${ }^{21}$ R. Valentina Sagala, Ellin Rozana, 2007, Memberantas Trafficking Perempuan dan Anak, Bandung, Hlm. 86

22 Novianti, Tinjauan Yuridis Kejahatan Perdagangan Manusia (Human Traffikking) Sebagai Kejahatan Lintas Batas Negara, Jurnal Ilmu Hukum 2014, Hlm. 51
3) International Covenant on Economic, Social and Cultural Rights;

4) Convention on the Rights of the Child and its relevant Optional Protocol;

5) Convention Concerning the Prohibition and Immediate Action for the Elimination of the Worst Forums of Child Labor (ILO No. 182)

6) Convention on the Elimination of All Forms of Discrimination against Women;

7) United Nations Protocol to Suppress, Prevent and Punish Trafficking in Persons especially Women and Children supplementing the Convention against Transnational Organized Crime;

8) SAARC Convention on Combating Trafficking in Women and Children for Prostitution.

Dalam Article 4 Universal Declaration of Human Rights (UDHR) disebutkan bahwa "no shall be held in slavery or servitude: slave trade shall be prohibited in all their forms". Ketentuan dalam Article 4 secara jelas melarang perbudakan dan perdagangan budak. Larangan perbudakan juga terdapat dalam The International Covenant on Civil and Political Rights (ICCPR). Dengan kalimat yang berbeda tetapi memiliki makna yang sama dengan ketentuan sebagaimana terdapat dalam Article 4 (UDHR), Article 8 (ICCPR) secara jelas menyatakan bahwa "no one shall be held in Slavery: Slavery and the slave-trade in all their forms shall be prohibited". Dengan demikian jelas bahwa perbudakan merupakan suatu larangan. 
Dalam UDHR dan ICCPR, tidak dijelaskan apa yang dimaksud dengan "slavery". Pengertian "slavery", menurut Convention of Slavery (1926) adalah "the status or condition of a person over whom any or all of the powers attaching to the rights of ownership are exercised". Dalam pengertian ini termasuk pula membeli, menjual, dan mengadakan transportasi terhadap orang dengan maksud untuk melakukan eksploitasi, guna memperoleh keuntungan.

Hukum Humaniter Internasional, menentang dan melarang segala bentuk "slavery". Bahkan, masalah yang berkaitan dengan "slavery" dikualifikasikan sebagai kejahatan internasional, selain kejahatan perang (war crime) dan kejahatan terhadap kemanusiaan (crimes against humanity). Oleh karena itulah, masalah ini menjadi masalah yang penting bagi setiap negara untuk melakukan pelarangan dalam hukum nasionalnya, sekalipun dalam keadaan perang ataupun keadaan darurat. $^{23}$

Permasalahan yang berkaitan dengan anak, tidak lepas dari perhatian masyarakat internasional. The

International Convention on the Rights of the Child/CRC (Konvensi Hak Anak). Pasal 32 CRC menegaskan bahwa setiap negara wajib mengedepankan perlindungan anak dari segala macam bentuk eksploitasi atau pekerjaan yang mengakibatkan kerusakan atau mengganggu pendidikan anak, atau yang mengancam kesehatan fisik, mental,

\footnotetext{
${ }^{23}$ Harkristuti Harkrisnowo, Op.Cit. hlm. 20
}

spiritual anak, maupun perkembangan sosial lainnya. Pasal $35 \mathrm{CRC}$ juga mewajibkan pemerintah membuat langkah-langkah multilateral untuk mencegah penculikan dan perdagangan anak untuk tujuan apapun, serta memberikan pula pelayanan program sosial, menyediakan dukungan yang sesuai dengan anak. ${ }^{24}$

Hukum internasional, juga memberikan perlindungan kepada individu-individu, sebagai migrant atau pekerja migrant. Instrumen internasional yang berkaitan dengan hal tersebut adalah Convention on the Protection of the Rights of All Migrant Workers and Members of Their Families. Pasal 10 Konvensi ini menegaskan bahwa pekerja migran dan keluarganya wajib dihindarkan dari segala macam bentuk siksaan, hambatan, dan perilaku yang tidak manusiawi, termasuk di dalamnya larangan untuk memperbudak, perlakuan yang tidak manusiawi. ${ }^{25}$

Kemudian Convention Against Torture and Other Cruel, Inhuman or Degrading Treatment or Punishment (Konvensi Menentang Penyiksaan dan Perlakuan atau Hukuman Lain yang Kejam, Tidak Manusiawi, dan Merendahkan Martabat Manusia), mengatur tentang larangan memperlakukan seseorang menjadi sasaran penyiksaan, dan perlakuan

Maslihati Nur Hidayati, Upaya
Pemberantasan dan Pencegahan Perdagangan
Orang Melalui Hukum Internasional dan Hukum
Positif Indonesia, Jurnal AL-AZHAR
INDONESIA SERI PRANATA SOSIAL, Vol. 1,
No. 3, 2012, Hlm. 173
${ }_{25}$ Maslihati Nur Hidayati, Loc.Cit, Hlm. 173


Deypend Tommy Sibuea: Pemberantasan Perdagangan Orang Melalui Instrumen Hukum..

hukuman lain yang kejam dan tidak manusiawi atau merendahkan martabat manusia.

Satu instrumen lagi yang perlu mendapatkan perhatian adalah South Asian Association for Regional Cooperation (SAARC) Convention on Preventing and Combating Traffiking in Women and Children for Prostitution. SAARC dimaksudkan untuk mencegah dan membasmi perdagangan wanita dan anak, dengan tujuan untuk prostitusi di wilayah Asia Selatan yang memang menjadi wilayah dengan banyak kasus perdagangan wanita dan anak.

\section{b. Instrumen Nasional}

Perdangangan orang, khususnya perempuan dan anak, merupakan tindakan yang bertentangan dengan harkat dan martabatnya yang dilindungi oleh undangundang berdasarkan Pancasila dan Undang-Undang Dasar 1945, manusia dan melanggar hak asasi manusia, sehingga harus diberantas. Sesuai dengan bunyi Pasal 20 Undang-Undang Nomor 39 Tahun 1999 tentang Hak Asasi Manusia, menyatakan bahwa: Tiada seorangpun boleh diperbudak atau diperhamba; Perbudakan atau perhambaan, perdagangan budak, perdagangan wanita, dan segala perbuatan berupa apapun yang tujuannya serupa, dilarang.

Di Indonesia tindak pidana perdagangan manusia diatur dalam Undang-Undang Nomor 21 Tahun 2007 Tentang Pemberantasan Tindak Pidana Perdagangan Orang. Orang yang diperdagangkan (korban trafficking) adalah seseorang yang direkrut, dibawa, dibeli, dijual, dipindahkan, diterima atau disembunyikan. Modusnya bermacammacam. Ada yang dengan cara ancaman, penggunaan kekuasaan verbal dan fisik, penculikan, penipuan, tipu muslihat, memanfaatkan posisi kerentaan (misalnya ketika seseorang tidak memiliki pilihan lain), terisolasi, ketergantungan obat, jebakan. $^{26}$

Pelaku dari tindak pidana ini dapat dijerat dengan Pasal 2 ayat (1) UndangUndang Nomor 21 Tahun 2007 Tentang Tindak Pidana Perdagangan Orang. Dalam pasal tersebut dijelaskan rincian sanksi yang dapat dijatuhkan. Lebih lengkapnya pasal tersebut berbunyi:

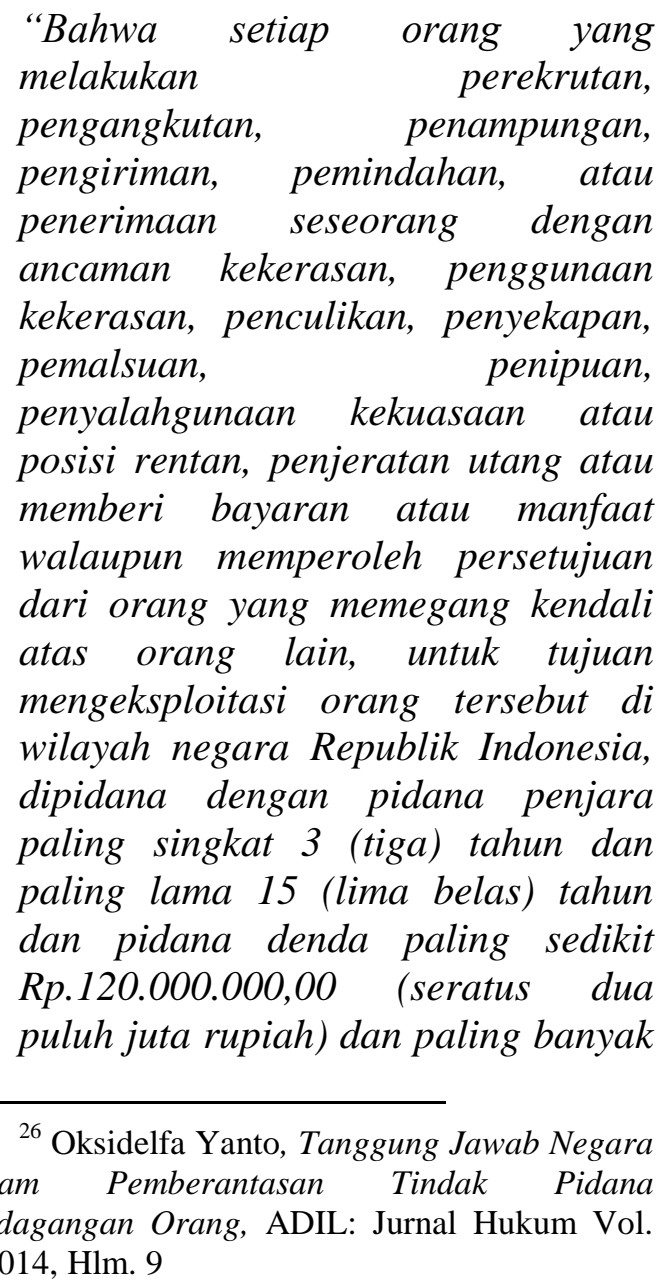


Rp. 600.000.000,00 (enam ratus juta rupiah)".

Sanksi yang sama ini juga berlaku untuk dikenakan pada setiap tindakan yang dilakukan oleh pelaku yang mengakibatkan orang tereksploitasi.

Di samping ketentuan khusus Undang-Undang Trafficking diatas, pengaturan perdagangan manusia juga dapat dilihat sanksinya dalam Pasal 297 KUHP yang berbunyi:

"Memperdagangkan perempuan dan laki-laki yang belum dewasa dihukum penjara selama-lamanya enam tahun".

Kemudian juga dalam Pasal 324 KUHP yang berbunyi:

"Barangsiapa dengan biaya sendiri atau orang lain menjalankan perniagaan budak belian atau melakukan perbuatan perdagangan budak belian atau dengan sengaja turut campur dalam hal itu, baik langsung maupun tidak langsung, dihukum penjara selama-lamanya dua belas tahun".

Mengingat korban dari perdagangan manusia termasuk juga anak-anak, maka pengaturannya selain dalam UU Nomor 21 tahun 2007 juga diatur dalam UndangUndang Nomor 23 Tahun 2002 Tentang Perlindungan Anak. Undang-Undang Perlindungan Anak sudah memuat ketentuan mengenai perdagangan anak dalam beberapa pasalnya, antara lain Pasal 78 yang berbunyi:

"Setiap orang yang mengetahui dan sengaja membiarkan anak dalam situasi darurat sebagaimana dimaksud dalam Pasal 60, anak yang berhadapan dengan hukum, anak dari kelompok minoritas dan terisolasi, anak yang tereksploitasi secara ekonomi dan/atau seksual, anak yang diperdagangkan, anak yang menjadi korban penyalahgunaan narkotika, alkohol, psikotropika, dan zat adiktif lainnya (napza), anak korban penculikan, anak korban perdagangan, atau anak korban kekerasan sebagaimana dimaksud dalam Pasal 59, padahal anak tersebut memerlukan pertolongan dan harus dibantu, dipidana dengan pidana penjara paling lama 5 (lima) tahun dan/atau denda paling banyak $R p$ 100.000.000,00 (seratus juta rupiah)."

Pasal 83 menyatakan bahwa:

"Setiap orang yang memperdagangkan, menjual, atau menculik anak untuk diri sendiri atau untuk dijual, dipidana dengan pidana penjara paling lama 15 (lima belas) tahun dan paling singkat 3 (tiga) tahun dan denda paling banyak $R p$ 300.000.000,00 (tiga ratus juta rupiah) dan paling sedikit $R p$ 60.000.000,00 (enam puluh juta rupiah)".

\section{KESIMPULAN}

Dari uraian di atas dapat disimpulkan bentuk-bentuk perdagangan manusia yaitu eksploitasi seksual kerja paksa, perbudakan dalam rumah tangga; adopsi anak antar negara secara ilegal, penjeratan utang, dan pengantin pesanan.

Selain itu, kejahatan perdagangan manusia bisa terjadi disebabkan oleh faktor-faktor yaitu kemiskinan, perpindahan penduduk dan diskriminasi serta budaya patriarki. 
Deypend Tommy Sibuea: Pemberantasan Perdagangan Orang Melalui Instrumen Hukum..

Dalam upaya pemberantasan dan pencegahan kejahatan perdagangan manusia, sejatinya telah ada pengaturan mengenai perdagangan orang, baik secara internasional maupun nasional. Intrumen internasional telah mencatat beberapa konvensi diantaranya, Universal Declaration of Human Rights; International Covenant on Civil and Political Rights; International Covenant on Economic, Social and Cultural Rights; Convention on the Rights of the Child and its relevant Optional Protocol; Convention Concerning the Prohibition and Immediate Action for the Elimination of the Worst Forums of Child Labor (ILO No. 182); Convention on the Elimination of All Forms of Discrimination against Women; United Nations Protocol to Suppress, Prevent and Punish Trafficking in Persons especially Women and Children supplementing the Convention against Transnational Organized Crime; SAARC Convention on Combating Trafficking in Women and Children for Prostitution.

Selain instrumen internasional yang berbentuk konvensi di atas, Indonesia juga mempunyai peraturan perundangundangan yang dapat digunakan untuk mencegah maupun menindak kejahatan perdagangan manusia antara lain. Kitab Undang-Undang Hukum Pidana (KUHP), Undang-Undang Nomor 39 Tahun 1999 tentang Hak Asasi Manusia. UndangUndang Nomor 23 Tahun 2003 tentang Perlindungan Anak, dan Undang-Undang Nomor 21 Tahun 2007 tentang
Pemberantasan Tindak Pidana Perdagangan Orang.

Mengingat betapa sudah sangat berbahayanya tindak pidana perdagangan manusia, maka sudah seharusnya negara atau pemerintah Indonesia mempunyai tanggung jawab untuk mencegah dan menanggulangi perdagangan manusia. Apalagi Indonesia punya peraturan khusus. Dengan peraturan perundangundangan khusus yang sudah ada, sepantasnyalah pemerintah Indonesia menjerat pelakunya demi terlindunginya para korban.

\section{UCAPAN TERIMA KASIH}

Dengan mengucapkan Puji dan Syukur ke hadirat Tuhan Yang Maha Esa, karena atas Rahmat dan Karunia-Nya, akhirnya penulis mampu menyelesaikan penulisan karya ilmiah ini yang berjudul: "Pemberantasan Perdagangan Orang Melalui Instrumen Hukum Nasional Dan Hukum Internasional Di Indonesia".

Penulis menyadari bahwa tanpa bantuan dan dorongan dari berbagai pihak tidak mungkin karya ilmiah ini dapat diselesaikan. Oleh karena itu pada kesempatan ini dengan segala kerendahan hati, penulis ingin mengucapkan terima kasih dan penghargaan yang sebesarbesarnya kepada:

1. Bapak Dr. Eviandi Ibrahim S.H., M.Hum selaku Ketua Sekolah Tinggi Ilmu Hukum Putri Maharaja Payakumbuh, yang telah memberikan kesempatan bagi penulis untuk 
menyumbangkan tulisan di Jurnal Cendekia Hukum.

2. Seluruh Bapak/Ibu Dosen dan rekanrekan mahasiswa di Fakultas Hukum Universitas Diponegoro, tempat bagi penulis menimbah ilmu yang tidak dapat disebutkan satu-persatu.

\section{DAFTAR PUSTAKA}

Buku

Harkristuti Harkrisnowo, 2003, Laporan Perdagangan Manusia di Indonesia, Sentra Ham UI, Jakarta.

Mahrus Ali, Bayu Aji Pramono, 2011, Perdagangan Orang: Dimensi, Instrumen Internasional dan Pengaturannya di Indonesia, Citra Aditya Bakti, Yogyakarta.

Nurhenny H, 2010, Tindak Pidana Perdagangan Orang Kebijakan Hukum Pidana dan Pencegahannya, Sinar Grafika, Jakarta.

R. Valentina Sagala, Ellin Rozana, 2007, Memberantas Trafficking Perempuan dan Anak, Bandung.

\section{Makalah dan Artikel}

Maslihati Nur Hidayati, 2012, Upaya Pemberantasan dan Pencegahan Perdagangan Orang Melalui Hukum Internasional dan Hukum Positif Indonesia, Jurnal Al-Azhar
Indonesia Seri Pranata Sosial, Vol. 1, No. 3

Meril Enugene Anthes, 2005, Chester James Taylor 2005 Grand Prize Winner: Regarding Women and Children: Using International Trade Relations to Stem the Growing Tide of the Sexula Exploitation of Women and Children, International Trade Law Journal, Vol. 14.

Novianti, 2014, Tinjauan Yuridis Kejahatan Perdagangan Manusia (Human Traffikking) Sebagai Kejahatan Lintas Batas Negara, Jurnal Ilmu Hukum

Oksidelfa Yanto, Tanggung Jawab Negara Dalam Pemberantasan Tindak Pidana Perdagangan Orang, ADIL: Jurnal Hukum Vol. 5,2014

Sasha L. Nel, 2011, Victim of Human Trafficking: Are They Adequately Protected in the United States?, Chicago-Kent Jurnal of International and Comparative Law

Shelly Case Inglis, Expanding International and National Protections Againts Trafficking for Forced Labor Using a Human Rights Framework, Buffalo Human Right Law Review, Vol. 7, 2001 